\title{
Physico-chemical and Microbiological Assessment of Drinking Water Quality from Different Sources in Digalu-tijo Woreda(District), Oromia Regional State, Ethiopia
}

\author{
AlemayehuDaba* Beyene Dobo ${ }^{1}$ Zufan Bedewi ${ }^{2}$ \\ 1,2,3 Hawassa University, Department of Biology, P. O. Box: 05, Hawassa, Ethiopia
}

\begin{abstract}
Human health depends on safe water more than any other things. The objective of present study was to determine the physico-chemical and bacteriological quality of water from different sources. To do this, a crosssectional study was conducted and a total of 62 water samples we collected from five different water sources and eight physico-chemical parameters(turbidity, temperature, dissolved oxygen, Electrical conductivity, $\mathrm{pH}$, total dissolved solids, chloride and nitrate and two microbiological parameters(total coliform and faecal coliform) were analyzed using the Membrane filtration method. The physicochemical parameter results ranged in the following trends: Turbidity $50.90 \pm 1.4$ to $1.82 \pm 0.13 \mathrm{NTU}$, Temperature $18.25 \pm 0.57$, to $16.17 \pm 0.29^{\circ} \mathrm{C}$, Dissolved oxygen $4.83 \pm 0.07$ to $3.05 \pm 0.05 \mathrm{mg} / \mathrm{l}$, Electrical conductivity $1030.2 \pm 41.8$ to $93.46 \pm 16.11 \mu \mathrm{S} / \mathrm{cm}, \mathrm{pH} 7.75 \pm 0.15$ to $7.13 \pm 0.12$, Total dissolved solids $515.0 \pm 21.0$ to $46.76 \pm 8.05 \mathrm{in} \mathrm{mg} / \mathrm{l}$, Chloride $43.00 \pm 6.00$ to $9.29 \pm 1.07 \mathrm{mg} / \mathrm{l}$, Nitrate $34.0 \pm 8.00$ to $1.34 \pm 0.17 \mathrm{in} \mathrm{mg} / \mathrm{l}$, Total coliform $342.5 \pm 255.5$ to $12.00 \pm 1.25 \mathrm{cfu} / 100 \mathrm{ml}$ and faecal coliform $82.5 \pm 23.5$ to $5.25 \pm 0.78 \mathrm{in} \mathrm{cfu} / 100 \mathrm{ml}$. The results indicated that all the physicochemical parameters of all water sources in Digalu-Tijo woreda were found within and below the range of National and International standards except Turbidity (USOS (11.1\%), UHDW and UR), Temperature (PSWDS, UHDW, UD and TW) and PH (7.4\% of USOS). However, $93.5 \%$ the water samples were found to harbor coliform in numbers greater than the required. So, majority of the drinking water sources had unacceptable quality or were grossly polluted particularly unprotected Hand dug well and River. Therefore, regular quality control mechanisms, proper sanitation and drainage network system should be given priority to ensure safety of drinking water.
\end{abstract}

Keywords: Bacteriological parameters, Coliform, Physico-chemical parameters, sanitary survey inspection,

Water quality

DOI: $10.7176 / \mathrm{JNSR} / 10-3-01$

Publication date: February $29^{\text {th }} 2020$

\section{Introduction}

Water is the most common, wildly distributed and useful liquid on the earth (Qadeer, 2005). Water serves as lubricant regulates the body temperature and provides the basis for the body fluids and metabolism (Staci, 2005). It is a good solvent and picks up impurities easily and thus changes its taste, colour and odour. According to USEPA (1997), socioeconomic development processes are closely related to the water resources, because of the diverse range of interaction between water and human activities, water serves as positive inputs for many activities likes as essential biological functions, as a basic element of social and economic infrastructure and as a natural amenity contributing to physiological welfare. Water also serves in negative roles such as flooding and disease transmission. The significant magnitude and pervasive nature of these positive and negative attributes creates a close relationship between water and human welfare (USEPA, 1997).

Water quality changes due to physical, biological and chemical conditions that occur as results of physical and anthropogenic activities (Kar, 2008). Water quality refers to the characteristics of a water supply that will influence its suitability for specific use i.e. how well the quality meets the needs of the user; quality is defined by certain physical, chemical, and biological characteristics (FAO, 2002). The quality of water is strongly influenced by community uses such as agriculture, urban and industrial use, and recreation.

Water sources have increasingly become polluted with municipal sewage, industrial waste, industrial toxics, heavy metals, fertilizers, chemicals, radioactive substances and land sediment, particularly for down streams, which lack proper water treatment and filtering facilities, public health is seriously threatened by polluted drinking water (Zewdie Abate, 1994; APHA, 1998). It is well-known fact that when water is polluted, its normal functioning and properties are affected (Trivedi et al., 2010). When drinking water gets contaminated with various pathogenic microorganisms and toxic chemical compounds, then it serves as the main source ofepidemic infectious diseases like typhoid, cholera, infectious hepatitis and infant diarrheal which are responsible for mortalities and morbidities in a large-scale (Andrea Versari, 2002).

According to $\mathrm{WHO}$, more than $80 \%$ of diseases in the world are attributed to unsafe drinking water or to inadequate sanitation practices (WHO, 2003a). Diarrhea remains a major killer in children and it is estimated that $80 \%$ of all illness in developing countries is related to water and sanitation; and that $15 \%$ of all child deaths under the age of 5 years in developing countries results from diarrheal diseases (WHO, 2003a; 2004b), moreover, 
a humanitarian crisis kills about 3900 children every day and thwarts progress towards all the Millennium Development Goals (MDGs), especially, in Africa and Asia (Bartramet al., 2005). Dada and Ntukepo (1997) reported that $30 \%$ of Nigerians have access to portable water and also stated that $80 \%$ of all diseases and over $30 \%$ of deaths are water related.

Ethiopia is naturally endowed with abundant water resources that help to fulfill domestic requirements, irrigation and hydropower. With its current per-capita fresh water resources estimated at $1924 \mathrm{~m}^{3}$ and this indicate that the country is one of the sub-Saharan African countries endowed with the largest surface fresh water resource. However, only $2 \%$ of the potential is annually utilized (FDRE, MoWR, 2002). In Ethiopia drinking water coverage was less than or equal to $21 \%$ for the rural, $84 \%$ for the urban and $30 \%$ for the country level. The per capita per day water consumption ranged from 3 to 20 liters with median of 8.5 liters (Abera and Mohamed, 2005).

In rural areas and villages of Ethiopia, water for human consumption, drinking, washing (bathing, laundry), for preparation of food etc, is obtained from rivers, streams, shallow wells, springs, lakes, ponds, and rainfall andall these sources are contaminated with human excreta, animal waste and effluent because of open field defecation practices. Thus, the majority of rural communities use water from contaminated or doubtful sources, which expose the people to various water-borne diseases (FDRE, MoWR, 2004). As a result, more than $75 \%$ of the health problems in Ethiopia are due to communicable diseases attributed to unsafe and inadequate water supply, and unhygienic waste management, particularly human excreta (UN-WATER/ WWAP/, 2004). So, Ethiopia is one of the countries with worst health status in the world water quality problems. The problem is the backward socio-economic development resulting in one of the lowest standard of living, poor environmental conditions and low level of social services (UN-WATER/WWAP/, 2004).

In addition to causing healthproblems, when waste products are introduced in to water bodies it creates change in physical, chemical and biological water quality parameters such as infectious agents, temperature, turbidity, color, $\mathrm{pH}$, salinity and oxygen concentration. Changes in any of this parameter have direct environmental effects and can also produce impact by modifying other parameters (Hem, 1985; Chapman, 1996).

Detection, differentiation and enumeration of bacteria are of primary importance in the microbiological quality control of water. Indicator bacteria are used to evaluate the potability of drinking water because it would be impossible to accurately enumerate all pathogenic organisms that are transmitted by water. The use of indicator organisms, in particular the coliform group, as a means of assessing the potential presence of waterborne pathogens has been of paramount importance in protecting public health. The principle of the detection of selected bacteria that are indicative of either contamination or deterioration of water quality has been the foundation upon which protection of public health from water-borne diseases has been developed (Barrell et al., 2002).

The presence of any coliform organism in drinking water is used as an indicator of fecal contamination since they are the most sensitive indicator bacteria for demonstrating excremental contamination. WHO (2004a) bacteriological guidelines and Federal Democratic Republic of Ethiopia, Ministry of Water Resources (2002) for drinking water recommend zero total coliform and fecal streptococci/100 $\mathrm{ml}$ of water. Therefore, this study is used to evaluate two microbial indicators and eight physio-chemical parametersof drinking water quality from different water source samples.

\section{Materials and Methods}

\subsection{Description of the Study Area.}

Digalu-Tijo woreda is found in Arsi Administrative Zone, Oromia Regional State which is located at $198 \mathrm{~km}$ from Addis Ababa, capital city of Ethiopia. Geographically it is located at latitude of $7^{\circ} 35^{\prime} 57^{\prime \prime}-7^{\circ} 55^{\prime} 43^{\prime \prime} \mathrm{N}$ and longitude of $38^{\circ} 59^{\prime} 40^{\prime \prime}-39^{\circ} 24^{\prime} 31^{\prime \prime} E a n d$ bounded in the East by Seru Woreda, in the West by Munesa Woreda, in the North by Lemu-Bilbilo Woreda and in the South by Tiyo Woreda and has 23 rural and 4 urban kebeles. The total land use and land cover of the woreda is about 92698.51 ha. of which $41551,23158.96,8650.5$ and 19338.05 ha. are farmland, forest land, grazing land and others respectively. The district represent areas with mid altitude (2000 - 4000 m.a.s.1.) receiving mean annual rainfall ranges from 1000 to $1500 \mathrm{~mm}$ and mean annual temperature ranges from $15-22{ }^{\circ} \mathrm{C}$. The woreda's agro-ecological climatic zones are Dega (78 \%) and woynedega $(22 \%)$ having $44 \%$ of red, $35 \%$ of black and $21 \%$ of brown soil types. Digalu-Tijo woreda is an agrarian economy based woreda where the agricultural sector plays an important role in theireconomic center in addition to animal rearing. So, people engaged in mixed farming system that is crop cultivation and animal rearing (Digalu-Tijo woreda Atlas, 2015).

\subsection{Sample size Determination and Sampling Techniques}

In Digalu-TijoWoreda there are 145 water points, of which 62 unprotected springson Spot (USOS), 8Unprotected Hands Dug Wells (UHDW), 4 unprotected Rivers (UR), 14Protected Springs with Distribution System (PSWDS) and 57 water extensions constructed by government and different Non-Governmental 
Organizations. Due toresource and timelimitation,only5studyareas or kebeles (Digalu Kidame, AymuraB oladana, Lole Abosara, Gusha Temala and Sagure town) and 62 water points were selected using simple random sampling technique which is determined by using the following statistical formula (Kothari, 1990).

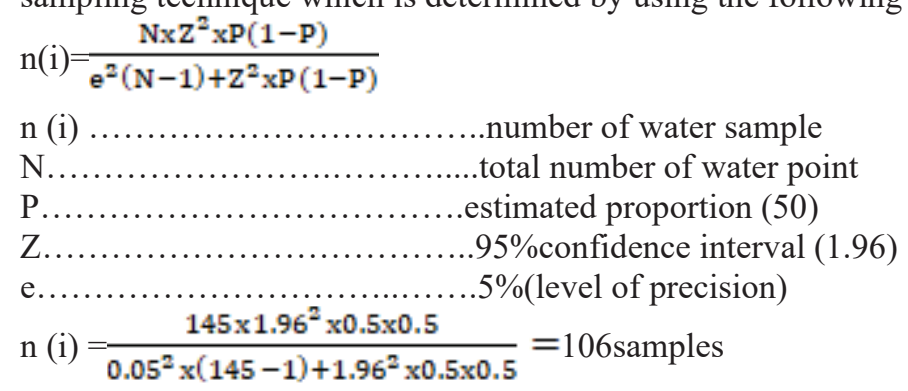

Now, by using sample reduction formula or finite population correction (Cochran, 1963);

$n=\frac{n(i)}{1+\frac{n(i)-1}{N}}$, where $n$-is reduced sample

$\mathrm{n}=\frac{106}{1+\frac{106-1}{145}}=62$ water samples

Table1. Number of samples determined fromthe population.

\begin{tabular}{|c|c|c|c|}
\hline Water Points found in the district & $\begin{array}{l}\text { Number of Water } \\
\text { sources(population) }\end{array}$ & $\begin{array}{l}\text { Reduced Sample (By } \\
\text { reduction formula) }\end{array}$ & Sample \\
\hline Unprotected Spring on Spot(USOS) & 62 & 27 & \\
\hline Protected Spring with Distribution & & & \\
\hline System(PSWDS) & 14 & 6 & \\
\hline Unprotected Hand Dug Well(UHDW) & 8 & 3 & \\
\hline Unprotected River(UR) & 4 & 2 & \\
\hline Tap Water(TW) & 57 & 24 & \\
\hline Total & 145 & 62 & \\
\hline
\end{tabular}

Finally, water samples from twelve water sources comprising three unprotectedsprings on spot, two springs with distribution system, two unprotectedHand-dug wells, three tap waters and two unprotected Rivers (Kathari, 1990) were analyzed.

\subsection{Water Sample Collection Procedures}

Sample collection and preservation techniques were based on the standard method of water sampling and preservation procedures (APHA, 1998). Water samples were collected fromeach study area (unprotectedspringon Spot, protectedspring with Distribution System, unprotected Hand Dug Well, Tap water and unprotectedRiver) for microbial and physico-chemical laboratory analysis aseptically in sterile plastic bottles. Triplicate samples (to aid in quality assurance) were collected in $100 \mathrm{ml}$ polyethylene bottles, labeled and then the samples were kept in ice-box during transportation to Asella water supply and sewerage enterprise and Asella TVET College for microbial and physico-chemical quality analysis. Water sample collections were mostly carried out during dry seasons since flooding might affect the spatial and temporal variation of water quality.

\subsection{Sanitary Data Collection}

Besides water sample collection, additionalinformation were collected from one urban (Sagure town) having 6 residents ( 2 males and 4 females) and from four rural having 24 residents (10 males and 14females) total 30 residents (12 males and 18 females)that live near the study areas and woreda's administrative office of water supply that were selected by using non-probability sampling (purposive technique) through structured interview after translated to Afaan Oromo to make communication simple and to get reliable data for sanitary inspection.

\subsection{Experimental Design and Analytical procedure of Physico-chemical and Microbiological Parameters 3.5.1 The Physico-chemical Characteristics of Drinking Water}

Cross sectional study were done to examine the related physico-chemical quality of drinking water at different sources. The analyses of various physicochemical parameters were carried out following the method described by Rodier (2009). The temperature, potential of hydrogen $(\mathrm{pH})$ and electrical conductivity(EC)were determined with mercury filled centigrade thermometer calibrated to $0^{\circ} \mathrm{c}$ to $100^{\circ} \mathrm{c}$,Portable digital $\mathrm{pH}$ meter (Model PD 300), and electrical conductivity meter(APHA, 1998) at the timeof sample collection respectively. Chlorides $\left(\mathrm{Cl}^{-}\right)$were determined by the volumetric method with dinitrate mercury $\mathrm{Hg}\left(\mathrm{NO}_{3}\right)_{2}$ in the presence of a $\mathrm{pH}$ indicator and total suspended solid (TDS) using gravimetric analysis.Nitrate $\left(\mathrm{NO}_{3}{ }^{-}\right)$, was determinedby a colorimetric method 
using a UV-Visible spectrophotometertype (JASCO V-530). DO and Turbidity were measured according to APHA (1998), using PD 300 water proof portable meter anddigital Turbid meter (WAGWE30140).

\subsubsection{Microbial Analysis}

The samples were analyzed for total coliform (TC) and faecal coliform (FC) using the membrane filter technique as outlined by the APHA (1998). 100ml of water sample from each study area was mixed thoroughly by shaking for a total 30 minutes andplaced on the surface of a sterile and gridded membrane filter with pore size $0.45 \mu \mathrm{m}$ and $47 \mathrm{~mm}$ diameter placed on funnel unit of the membrane filter support assembly. The filtration was facilitated by applying a vacuum pump and the assembly was rinsed by sterile dilute water (APHA, 1998).

After the filtration processes were completed, the bacteria remained on the filter papers were placed on nutrient mediumin Petri dishes with agar solution (Eosin Methylene Blue agar).Eosin Methylene Blue (EMB) agarcontains lactose, sucrose and dyes; eosin and methylene blue are used as indicators that is used to recognize typical colony morphology characteristics ofdifferent bacterial group. The EMB is commonly used in water quality tests to distinguish total coliform and fecal coliform that signal possible pathogenic microorganism contamination in water samples (APHA, 1998). Finally, the cultures were incubated at $37^{\circ} \mathrm{c}$ for 18 to $24 \mathrm{hrs}$ (Burgess and Pletschke, 2008).

Upon completion of incubation period, coliform colonies (yellow color) were seen on the surface of membrane filter paper. All the yellow colonies extending on the membrane were counted as total coliform (TC) by using a low power binocular microscope and recorded as total coliform (APHA, 1998). For FC (E.coli) colonies count, the same procedure was followed, except temperature which is $44.5^{\circ} \mathrm{c}$ for 24 to $48 \mathrm{hrs}$ (Burgess and Pletschke, 2008). This elevated temperature shocks non-fecal bacteria and suppresses their growth. As the fecal coliform colonies grow they produce an acid (through fermenting lactose) that reacts with the dye in the medium thus giving the colonies blue color. After incubation period, a typical blue colored E.coli on the surface of membrane filter were counted by the aid of magnifying glass and recorded as FC (APHA, 1998). The number of colonies formed on the media was reported as colony forming units (CFU) per 100ml of samples. Finally, the total and fecal coliform qualities of water were reported based on the WHO and ESDWQ standards.

\section{Results and Discussions}

\subsection{Physicochemical Parameters}

Mean \pm SEM statistical analysis of physicochemical parameters, mean concentration of physicochemical analysis andcomparison of physicochemical quality of drinking water from different sources in Digalu-Tijo Woreda with WHO recommended value were presented in tables 2, 3, and 4 below.

\subsubsection{Turbidity}

Turbidity is one of the foremost parameter for the acceptability of drinking water qualitywhich is depends on a number of factors such as the size, shape, and refractive index of the clay, colloidal particles and the microorganisms (WHO, 1983). The observed mean values inthe studied samples for turbidity were varied from $50.90 \pm 1.4 \mathrm{NTU}$ to $1.82 \pm 0.13 \mathrm{NTU}$. The maximummean turbidity value was recorded inUnprotected River $(50.90 \pm 1.4)$ while the minimum mean turbidity value was recorded in Tap water (1.82 \pm 0.13$)$. The mean turbidity values of other water sources were $21.5 \pm 1.98,3.27 \pm 0.23 ; 2.16 \pm 0.11 \mathrm{NTU}$ for Unprotected Hand dug well, Unprotected Spring on spot and protected spring with distribution systemrespectively (Table 2).

Table 2. Mean \pm SEM statistical analysis of physicochemical parameters of drinking water samples from different sources.

\begin{tabular}{|c|c|c|c|c|c|c|c|c|c|}
\hline \multirow{2}{*}{$\begin{array}{l}\text { Water } \\
\text { sources }\end{array}$} & \multirow{2}{*}{$\mathrm{N}$} & \multicolumn{8}{|c|}{ Physicochemical parameters } \\
\hline & & $\begin{array}{l}\text { Turbidity } \\
\text { (NTU) }\end{array}$ & $\begin{array}{l}\text { Temperature } \\
\left({ }^{\circ} \mathrm{C}\right)\end{array}$ & $\mathrm{DO}(\mathrm{mg} / \mathrm{l})$ & $\mathrm{EC}(\mu \mathrm{S} / \mathrm{cm})$ & $\mathrm{pH}$ & TDS(mg/l) & $\mathrm{Cl}^{-}(\mathrm{mg} / \mathrm{l})$ & $\begin{array}{l}\mathrm{NO}_{3}^{-} \\
(\mathrm{mg} / \mathrm{l})\end{array}$ \\
\hline USOS & 27 & $3.27 \pm 1.19$ & $17.22 \pm 0.52$ & $4.83 \pm 0.07$ & $105.70 \pm 6.18$ & $7.74 \pm 0.12$ & $52.84 \pm 3.09$ & $13.40 \pm 1.47$ & $3.54 \pm 0.22$ \\
\hline PSWDS & 6 & $2.16 \pm 0.11$ & $17.18 \pm 0.52$ & $4.53 \pm 0.16$ & $93.46 \pm 16.11$ & $7.2 \pm 0.45$ & $46.76 \pm 8.05$ & $19.50 \pm 2.97$ & $2.88 \pm 0.13$ \\
\hline UHDW & 3 & $21.5 \pm 1.98$ & $18.25+0.57$ & $3.23 \pm 0.03$ & $780 \pm 106.79$ & $7.13 \pm 0.12$ & $390 \pm 53.39$ & $24.0 \pm 3.28$ & $17.0 \pm 2.64$ \\
\hline UR & 2 & $50.90 \pm 1.4$ & $18.0 \pm 2.0$ & $3.05 \pm 0.05$ & $1030.2+41.8$ & $7.75 \pm 0.15$ & $515.0 \pm 21.0$ & $43.00 \pm 6.00$ & $34.0 \pm 8.00$ \\
\hline TW & 24 & $1.82 \pm 0.13$ & $16.17 \pm 0.29$ & $4.37 \pm 0.10$ & $124.42 \pm 9.88$ & $7.6 \pm 0.15$ & $62.2 \pm 4.94$ & $9.29 \pm 1.07$ & $1.34 \pm 0.17$ \\
\hline
\end{tabular}

Key: USOS-unprotected spring on spot, PSWDS-protected spring with distribution system, UHDW-unprotected Hand dug well, UR-unprotected River, TW-Tap water, SD-standard deviation, and SE-standard error.

Turbidity of Unprotected Spring on spot $(88.9 \%)$, protected spring with distribution system, and Tap water of the samples analyzed met the acceptable level of WHO and National standard limit of pot ability which is less than 5 NTU(WHO, 2006) (Table 3), while the values of turbidity $11.1 \%$ of Unprotected spring on Spot, 100\% of Unprotected Hand dug well and Unprotected River water were greater thanthe recommended limit that is 5 NTU which is not acceptable to consumers (Table 4). Themaximum turbidity values observed atUnprotected Rivers(site3 and 4) and UnprotectedHand dug wells(site2 and 3)might be due to the fact that siteswerenormally deprived off vegetation cover during sampling periods and the lack of vegetation cover in such sites make the soil susceptible to wind erosion because rivers may get contaminated from soil runoff, that increases its turbidity. 
The consumption oflow turbidity minimizes both the amount of chlorine required for disinfection of water and the potential for transmitting infectious diseases. However, the consumption of high turbid water would be a health risk due to microorganism as the probable part in it may indicates the presence of disease causing organisms. These organisms include bacteria, viruses, and parasites that can cause symptoms such as nausea, cramps, diarrhea, and associated headaches (Akoto and Adiyiah, 2007; APHA, 1998). Moreover, high turbidity can also protect the pathogens from the effects of disinfectants, facilitate their growth and increase the chlorine demand (WHO, 1996, 2004a and 2004b).

\subsubsection{Temperature}

Temperature is one of the most important parameters for aquatic environment because almost all the physical, chemical and biochemical properties are temperature dependent. In the present study, the highest mean temperature concentration recorded was $18.25 \pm 0.57^{\circ} \mathrm{C}$ fromUnprotected Hand dug well particularly UHDW2 of site3followed by $18.0 \pm 2.0^{\circ} \mathrm{Cfrom}$ unprotectedRiver. The mean temperature values of other water sources were $17.23 \pm 0.52, \quad 17.18 \pm 0.52$, and $16.17 \pm 0.29^{\circ}$ Cfor Unprotected Spring on spot, protected spring with distribution system and Tap water respectively (Table 2 and 3 ).

All the temperatures observed under this study were above the permissible limit of $15^{\circ} \mathrm{C}$ recommended by WHO (1996) except $25.9 \%$ of USOS which did not meet the potability of drinking water (Table 4 ). When the temperature of the water is abovepermissible limit $\left(15^{\circ} \mathrm{C}\right)$, it can make the chance of biofilms (assemblage of microbial cellsirreversibly associated with solid surface) in the distributed water and increases the time of chlorine decay (WHO, 2006). Similar study in Italy by Sisti (1998) showed that the effect of chlorine compound was markedly influenced by water temperature that is the efficiency of chlorine tested was found to be two to three times lowered at $20^{\circ} \mathrm{C}$ as compared to $5^{\circ} \mathrm{C}$.Furthermore, high temperature can favor the growth of organisms in water resources (Muyima et al., 1998). A similar study in Italy showed that the survival at temperatures greater than $20^{\circ} \mathrm{C}$ increases curves of Aeromones spp. decline rapidly at low temperature that is $5^{\circ} \mathrm{C}$ (Sisti et al., 1998). So, all temperature observed under this study can increase pathogenic proliferation and survival that results the outbreak of water borne diseases.

\subsubsection{Dissolved Oxygen}

Oxygen is essential to all forms of aquatic life, including those organisms responsible for the self-purification processes in natural waters (Chapman, 1996). The mean dissolved oxygen concentration value recorded in spring on spot, spring with distributing system, unprotected Hand dug well, unprotected River and Tap water were $4.83 \pm 0.07,4.53 \pm 0.16,3.23 \pm 0.03,3.05 \pm 0.05$ and $4.37 \pm 0.10 \mathrm{in} \mathrm{mg} / \mathrm{l}$ respectively (Table2). The maximum mean value of dissolved oxygen was $4.83 \pm 0.07 \mathrm{mg} / 1$ in Unprotected Spring on spot (specially seen in USOS3) and the lowest value was $3.05 \pm 0.05 \mathrm{mg} / 1$ in Unprotected river (Table 2 and 3 ).

It was observed that in majority of thestudied samples, dissolved oxygen was less than the range of WHO recommended value which is $4.5-7.5 \mathrm{mg} / 1$ (WHO, 1996); however, 85.2\% of USOS and 66.7\% of PSWDS were withintherecommended value (Table 4). The variation in dissolved oxygen might be due to variation with temperature, salinity, the photosynthetic activity of algae and plants; the solubility of oxygen decreases as temperature and salinityincrease (Chapman, 1996).In fresh-waters dissolved oxygenat sea level ranges from 15 $\mathrm{mg} / \mathrm{l}$ at $0^{\circ} \mathrm{C}$ to $8 \mathrm{mg} / 1$ at $25^{\circ} \mathrm{C}$ which is similar tothe concentration of DO in the present study that ranges from $4.37 \mathrm{mg} / 1$ at $16.17^{\circ} \mathrm{C}$ to $3.23 \mathrm{mg} / 1$ at $18.25^{\circ} \mathrm{C}$ (Table 2).

According to Chapman (1996), oxygen concentrations in unpolluted waters are usually close to, but less than $10 \mathrm{mg} / \mathrm{l}$; however, wastedischarges high in organic matter and nutrients can lead to decreases in DO concentrations as a result of the increased microbial activity (respiration) occurring during the degradation of the organic matterthat may affect the survival of fish. There is no report of ill health effects arising directly from a deficiency of dissolved oxygen in potable water or from its complete absence exceptslight organoleptic(aesthetic e.g. taste, odor) significance(WHO, 1996; USEPA, 2001) and therefore, all DO in the current study had no health effect.

\subsubsection{Electrical Conductivity (Ec)}

Electrical Conductivity is a measure of the ability of aqueous solution to carry an electric current that depends on the presence and total concentrations of ions, their mobility and Valance (Clesceri, 1998). Electrical conductivity is a good and rapid method to measure the total dissolved ions and is directly related to total dissolved solids. The higher the value of dissolved solidsthe greater will be the amount of ions in water (Bhatt et al., 2000). The mean ECvalues of different water sources were in the range of $1030.2 \pm 41.8 \mu \mathrm{S} / \mathrm{cm}$ (inUnprotected River)to93.46 $\pm 16.11 \mu \mathrm{S} / \mathrm{cm}$ (in protected spring with distribution system) Table 2.From unprotected River, UR2 (Gusha River) of site 4 has recorded the highest value $(1072 \mu \mathrm{S} / \mathrm{cm})$ Table 3.The mean ECvalues of other water sources were $780 \pm 106.79,124.42 \pm 9.88$ and $105.70 \pm 6.18$ in $\mu \mathrm{S} / \mathrm{cm}$ for Unprotected Hand dug well, Tap water and Unprotected Spring on spot respectively (Table 2).

According to this study,EC of most of the analyzed samples(92\%) were found below WHO guidelines $(400-1200 \mu \mathrm{S} / \mathrm{cm})$ whereas samples fromUnprotected Hand dug wells and Unprotected Rivers $(8 \%)$ were the highest but found within WHO guidelines(WHO,1996)(Table 4). However, the current result of EC was in 
contrast with the research done in the urbanareas of Tigray Region from which very high values of EC with mean value of $1035,1663.09$ and $1793.6 \mu \mathrm{S} / \mathrm{cm}$ was recorded for samples collected from Indasilase, Mekelle and Axum respectively (Gebrekidan and Samuel, 2011). These fluctuations may be due to the effect of domestic sewage and inorganic fertilizer inputs discharged into them and accumulation of metal ions as a result of corrosion of metals. According to Kumar et al. (1996) it is also may be due to bicarbonate and calcium ions present in the soils. There is little direct health risk associated with conductivity of water, for example its high values are associated with poor taste, customer dissatisfaction andcomplaints, in addition to cause excessive scaling in water pipes, heaters, boilers and household appliances (Howard et al., 2003; WHO, 2004).

4.1.5. $\mathrm{pH}$

The mean $\mathrm{pH}$ values of the studied sample of water were between $7.13 \pm 0.12$ in Unprotected Hand dug well (the minimum mean value) and7.75 \pm 0.15 in Unprotected River (the maximum mean value). The mean PH value of other water sources were7.74 $\pm 0.12,7.6 \pm 0.15$ and7.2 \pm 0.45 for Unprotected Spring on spot, Tap water andprotected spring with distribution system respectively (Table2).

According to this study, most of the water samples met the WHO and Ethiopian drinking water quality standards for $\mathrm{pH}$ that is 6.5 to 8.5 (Chapman, 1996; ESDWQ, 2002); however, 33.3\% and 7.4\% of USOS was less than 6.5 andgreater than 8.5 respectively (Table 4). The highest values of $\mathrm{pH}$ recorded from UR is greater than the average $\mathrm{pH}$ values obtained from rivers in Addis Ababa (7.39), Kebena river (6.06) and in Akaki river (7.5) (TamiruAlemayehu et al., 2005). This variation may be due to UR mightbe associated with wastes thatreceived from human activities which can increase scale formation in heating vessels, reduce the bactericidal effect of Chlorine (Onuh and Isaac, 2009) and also favor both indicator and pathogenic microorganism's growth (Kent et al., 1988). In the other way, the lowest $\mathrm{pH}$ observed in UHDW (7.13 \pm 0.12 ) is in contrast to a $\mathrm{pH}$ value recorded from a well watersource (10.35), a research conducted by Zinabu and his collaborative in Quarite, Amhara Regional state (Zinabu et al., 2015)

$\mathrm{pH}$ values lower than 6.5 can lead to corrosion of pipesthat causesthe release of metals likeZinc, Lead and copper in to water samples, because the lower the $\mathrm{pH}$, the higher the level of corrosion (WHO, 1996; Chan et al., 2007). Low $\mathrm{pH}$ values recorded in some springsand opendug wells may be due tothe saturation of water sources with carbon dioxide as indicated in other studies (Byamukama et al., 1999) which is concorded with the current study (Table3)and most of the current water samples including the maximum and minimum value of $\mathrm{pH}$ had on health impact on consumers but some of USOS might be the cause for corrosion and growth of pathogenic micro-organism.

Table 3. Mean concentration of Physico-chemical analysis of Drinking water sample from different sources and sites.

\begin{tabular}{|c|c|c|c|c|c|c|c|c|c|c|}
\hline \multirow[b]{2}{*}{ Site } & \multirow{2}{*}{$\begin{array}{l}\text { Water } \\
\text { points }\end{array}$} & \multirow[b]{2}{*}{$\mathrm{N}$} & \multicolumn{8}{|c|}{ Mean physicochemical parameter } \\
\hline & & & $\begin{array}{l}\text { Turbidity } \\
\text { (NTU) }\end{array}$ & Temperature $\left({ }^{\circ} \mathrm{C}\right)$ & $\begin{array}{l}\mathrm{DO} \\
(\mathrm{mg} / \mathrm{l})\end{array}$ & $\begin{array}{l}\text { EC } \\
(\mu \mathrm{S} / \mathrm{cm})\end{array}$ & $\mathrm{PH}$ & $\begin{array}{l}\text { TDS } \\
(\mathrm{mg} / \mathrm{l})\end{array}$ & $\begin{array}{l}\mathrm{Cl}^{-} \\
(\mathrm{mg} / \mathrm{l})\end{array}$ & $\begin{array}{l}\mathrm{NO}_{3}^{-} \\
(\mathrm{mg} / \mathrm{l})\end{array}$ \\
\hline \multirow[t]{4}{*}{1} & USOS1 & 9 & 3.21 & 17.70 & 4.64 & 104.1 & 7.94 & 52.08 & 15.44 & 3.41 \\
\hline & PSWDS1 & 3 & 2.03 & 17.50 & 4.43 & 104.20 & 7.53 & 52.16 & 21.33 & 2.90 \\
\hline & TW1 & 8 & 1.87 & 15.37 & 4.68 & 134.75 & 7.90 & 67.37 & 11.37 & 1.03 \\
\hline & USOS2 & 9 & 3.65 & 17.33 & 4.80 & 112.73 & 7.57 & 56.36 & 12.00 & 3.30 \\
\hline \multirow[t]{2}{*}{2} & UHDW1 & 2 & 21.80 & 17.50 & 3.25 & 785.7 & 7.10 & 392.8 & 22.00 & 16.5 \\
\hline & TW2 & 8 & 1.85 & 17.00 & 3.97 & 124.25 & 7.32 & 62.12 & 8.00 & 1.67 \\
\hline \multirow[t]{2}{*}{3} & UHDW2 & 1 & 20.90 & 19.00 & 3.20 & 768.60 & 7.20 & 384.3 & 29.00 & 18.00 \\
\hline & UR1 & 1 & 49.5 & 20.00 & 3.10 & 988.4 & 7.90 & 494.00 & 37.00 & 26.00 \\
\hline \multirow[t]{2}{*}{4} & USOS3 & 9 & 2.95 & 16.65 & 5.00 & 100.18 & 7.71 & 50.08 & 12.77 & 3.53 \\
\hline & UR2 & 1 & 52.30 & 16.00 & 3.00 & 1072.00 & 7.60 & 536.00 & 49.00 & 42.00 \\
\hline \multirow[t]{2}{*}{5} & PSWDS2 & 3 & 2.30 & 16.86 & 4.63 & 82.73 & 6.86 & 41.36 & 17.66 & 2.86 \\
\hline & TW3 & 8 & 1.73 & 16.12 & 4.47 & 114.25 & 7.58 & 57.12 & 8.50 & 1.31 \\
\hline
\end{tabular}

Key: UR1- River 1(Kater River), UR2- unprotected River 2(Gusha River), DO-dissolved oxygen, EC-electrical conductivity, TDS-total dissolved solids, $\mathrm{Cl}^{-}$chloride ion $\mathrm{NO}_{3}{ }^{-}$nitrate ion,

\subsubsection{Total Dissolved Solids (TDS)}

The mean TDS value observed in the present study was varied from $515.0 \pm 21.0$ to $46.76 \pm 8.05 \mathrm{in} \mathrm{mg} / \mathrm{l} / . \mathrm{The}$ highest value was recorded in Unprotected River while the lowest value was recorded in protected spring with distribution system. The mean TDS value of other water samples were $390 \pm 53.39,62.2 \pm 4.94$ and $52.80 \pm 3.09$ $\mathrm{mg} / \mathrm{l}$ for Hand dug well, Tap water and Unprotected Spring on spot respectively (Table2).

Of the samples analyzed $98.38 \%$ were found to contain TDS value of less than500 mg/l whereas only $1.62 \%$ was found tocontaingreaterthan $500 \mathrm{mg} / 1$ mainly recorded from UR2 (536mg/l) Table3. However, the TDS concentration of all water sources were found to be lower than WHO guideline standards (WHO, 1993)(Table 4. The highest TDS value observed in UR $(515 \mathrm{mg} / \mathrm{l})$ was Concorded with the research conducted in Gondar town by Birtukan and her collaborative which state that the highest mean concentration of TDS recorded 
from Qeha River was 303mg/l which is less than current study. The variation may be due to difference in the concentration of inorganic salt and small amount of organic matter present inwater (E.g.arsenic, mercury)which can be dangerous for health even where their concentration is relatively low (AWWA,2000).

High TDS (more than500mg/l) result inexcessive scaling of water pipes and corrosion, water heater, boilers, and household appliances (Tihansky,1974); Moreover, high TDS increase density of water, decrease solubility of gases like oxygen, cause a bad odour or taste (due to excess salts in water), and ultimately make the water unsuitable for drinking (WHO, 2011).In contrast to this, when TDS level is less than $500 \mathrm{mg} / \mathrm{l}$ in drinking water, the palatability of water is generally considered to be good(London et al., 2005) and therefore, except UR(Table 4) all water sources of the present study were good for consumers.

\subsubsection{Chlorides}

The mean chloride ion concentration value of Unprotected Spring on spot, protected spring with distribution system, Unprotected Hand dug well, Unprotected RiverandTapwater were13.40 $\pm 1.47,19.50 \pm 2.97,24.33 \pm 3.28$, $43.00 \pm 6.00$ and $9.29 \pm 1.07 \mathrm{mg} / \mathrm{l}$ respectively (Table 2). From these, the maximum value was observed in unprotected River $(43.00 \pm 6.00 \mathrm{mg} / \mathrm{l})$ and the minimum value was recorded in Tap water $(9.29 \pm 1.07 \mathrm{mg} / \mathrm{l})$. From unprotected river, UR2 (Gusha river) demonstrated the highest concentration (49mg/l) as compared with other (Table3).

All chlorides values in the present study were lower than the standard of WHO guideline which is $250 \mathrm{mg} / 1$ and no health-based guideline value is proposed for chloride in drinking-water and so good for consumers (Table 2 and 4). According to the research conducted in Ethiopia by Zinabu (2015), the very high Chloride value recorded from spring water sources were $1399.6 \mathrm{mg} / \mathrm{l}$ and $5598 \mathrm{mg} / \mathrm{L}$ from Somali (Afder, Bare) and Oromia (North Shoa Ejere) respectively which is in contrast to this study(13.4mg/l)(Table 2.The highest chloride observed in Somali and Oromia may be due to high contamination of water source with natural sources, sewage and industrial effluents and urban runoff which had faecal origin (WHO, 2003). As a result of excessive chloride concentrations in water bodies, rates of corrosion of metals in the distribution system increase depending on the alkalinity of the water that can lead to increased concentrations of metals in the water supply.

\subsubsection{Nitrate $\left(\mathrm{NO}_{3}^{-}\right)$}

Nitrate is an essential nutrient for aquatic plants. It is end products of the decay of nitrogenous material such as nitrate fertilizers or animal and human excreta (Hutton, 1996). The highest mean nitrate concentration recorded in the current study was34.0 $\pm 8.00 \mathrm{mg} / 1$ from Unprotected River. ParticularlyUR2 (42mg/l) followed by $17.0 \pm 2.60$ $\mathrm{mg} / \mathrm{l}$ from Unprotected Hand dug well. The lowest mean nitrate concentration recordedwas $3.54 \pm 0.22,2.88 \pm 0.13$ and $1.34 \pm 0.17 \mathrm{in} \mathrm{mg} / \mathrm{l}$ from Unprotected Spring on spot, protected spring with distribution system, and Tap water respectively (Table 2 ).

The nitrate concentration in all samples of the current study were found to be by far very low which is less than the maximum concentration of nitrate for public water supplies that is $50 \mathrm{mg} / \mathrm{l}(\mathrm{WHO}, 1996)$ and therefore all water sources under this study does not pose any health problem. However, according to the research conducted in Asella town only $3.3 \mathrm{mg} / \mathrm{l}$ was recorded from UR which is very low as compared to the present study $(34 \mathrm{mg} / \mathrm{l})$. The high concentration of nitrate ion in UR may be due to its high contaminationwith human and animal wastes and inorganic nitrate fertilizer eroded into the river system during the disposal of wastewaters generated domestically and municipally (Melaku et al., 2007). In contrast to this research a study conducted in Jimma showed that there was very high nitrate concentration in protected springs that indicate the presence of organic pollution (Fariset al., 1999) which did not match with the current study. A high concentration of nitrate in drinking water was reported to cause shortness of breath (blue-baby syndrome) and other disorders (WHO, 2004). 
Table 4.Comparison of physicochemical quality of drinking water from different sources in Digalu-TijoWoreda with WHO recommended value.

\begin{tabular}{|c|c|c|c|c|c|c|c|c|c|c|c|c|}
\hline \multirow{2}{*}{$\begin{array}{l}\text { Physico- } \\
\text { chemical } \\
\text { parameters }\end{array}$} & \multirow{2}{*}{$\begin{array}{l}\text { WHO } \\
\text { Recommended } \\
\text { value }\end{array}$} & \multirow{2}{*}{$\begin{array}{l}\text { Recommended } \\
\text { level }\end{array}$} & \multicolumn{2}{|c|}{ USOS } & \multicolumn{2}{|c|}{ PSWDS } & \multicolumn{2}{|c|}{ UHDW } & \multicolumn{2}{|c|}{ UR } & \multicolumn{2}{|c|}{ TW } \\
\hline & & & $\mathrm{N}$ & $\%$ & $\mathrm{n}$ & $\%$ & $\mathrm{n}$ & $\%$ & $\mathrm{n}$ & $\%$ & $\mathrm{n}$ & $\%$ \\
\hline $\begin{array}{l}\text { Turbidity } \\
\text { (NTU) }\end{array}$ & Less than 5 & $\begin{array}{c}<5 \\
>5 \\
\text { Total } \\
\end{array}$ & $\begin{array}{c}24 \\
3 \\
27 \\
\end{array}$ & $\begin{array}{l}88.9 \\
11.1 \\
100 \\
\end{array}$ & $\begin{array}{l}6 \\
- \\
6 \\
\end{array}$ & $\begin{array}{c}100 \\
- \\
100 \\
\end{array}$ & $\begin{array}{l}- \\
3 \\
3 \\
\end{array}$ & $\begin{array}{c}- \\
100 \\
100 \\
\end{array}$ & $\begin{array}{l}- \\
2 \\
2 \\
\end{array}$ & $\begin{array}{c}- \\
100 \\
100 \\
\end{array}$ & $\begin{array}{c}24 \\
- \\
24 \\
\end{array}$ & $\begin{array}{c}100 \\
- \\
100 \\
\end{array}$ \\
\hline $\begin{array}{l}\text { Temperature } \\
\left({ }^{0} \mathrm{C}\right)\end{array}$ & Not exceed 15 & $\begin{array}{c}<15 \\
>15 \\
\text { Total } \\
\end{array}$ & $\begin{array}{c}7 \\
20 \\
27 \\
\end{array}$ & $\begin{array}{l}25.9 \\
74.1 \\
100 \\
\end{array}$ & $\begin{array}{l}- \\
6 \\
6 \\
\end{array}$ & $\begin{array}{l}- \\
100 \\
100\end{array}$ & $\begin{array}{l}- \\
3 \\
3\end{array}$ & $\begin{array}{c}- \\
100 \\
100 \\
\end{array}$ & $\begin{array}{l}- \\
2 \\
2 \\
\end{array}$ & $\begin{array}{c}- \\
100 \\
100 \\
\end{array}$ & $\begin{array}{c}- \\
24 \\
24 \\
\end{array}$ & $\begin{array}{c}- \\
100 \\
100 \\
\end{array}$ \\
\hline $\mathrm{DO}(\mathrm{mg} / \mathrm{l})$ & $4.5-7.5$ & $\begin{array}{c}<4.5 \\
4.5-7.5 \\
>8.5 \\
\text { Total } \\
\end{array}$ & $\begin{array}{c}4 \\
23 \\
- \\
27 \\
\end{array}$ & $\begin{array}{c}14.8 \\
85.2 \\
- \\
100 \\
\end{array}$ & $\begin{array}{l}2 \\
4 \\
- \\
6 \\
\end{array}$ & $\begin{array}{c}33.3 \\
66.7 \\
- \\
100 \\
\end{array}$ & $\begin{array}{l}3 \\
- \\
- \\
3\end{array}$ & $\begin{array}{c}100 \\
- \\
- \\
100 \\
\end{array}$ & $\begin{array}{l}2 \\
- \\
- \\
2\end{array}$ & $\begin{array}{c}100 \\
- \\
- \\
100 \\
\end{array}$ & $\begin{array}{c}24 \\
- \\
- \\
24 \\
\end{array}$ & $\begin{array}{c}100 \\
- \\
- \\
100 \\
\end{array}$ \\
\hline $\mathrm{EC}(\mu \mathrm{S} / \mathrm{cm})$ & $400-1200$ & $\begin{array}{c}<400 \\
400-1200 \\
>1200 \\
\text { Total } \\
\end{array}$ & $\begin{array}{c}27 \\
- \\
- \\
27 \\
\end{array}$ & $\begin{array}{c}100 \\
- \\
- \\
100 \\
\end{array}$ & $\begin{array}{l}6 \\
- \\
- \\
6\end{array}$ & $\begin{array}{c}100 \\
- \\
- \\
100 \\
\end{array}$ & $\begin{array}{l}- \\
3 \\
- \\
3\end{array}$ & $\begin{array}{c}- \\
100 \\
- \\
100 \\
\end{array}$ & $\begin{array}{l}- \\
2 \\
- \\
2\end{array}$ & $\begin{array}{c}- \\
100 \\
- \\
100 \\
\end{array}$ & $\begin{array}{c}24 \\
- \\
- \\
24 \\
\end{array}$ & $\begin{array}{c}100 \\
- \\
- \\
100 \\
\end{array}$ \\
\hline $\mathrm{PH}$ & $6.5-8.5$ & $\begin{array}{c}<6.5 \\
6.5-8.5 \\
>8.5 \\
\text { Total } \\
\end{array}$ & $\begin{array}{c}9 \\
16 \\
2 \\
27 \\
\end{array}$ & $\begin{array}{c}33.3 \\
59.3 \\
7.4 \\
100 \\
\end{array}$ & $\begin{array}{l}- \\
6 \\
- \\
6\end{array}$ & $\begin{array}{c}- \\
100 \\
- \\
100\end{array}$ & $\begin{array}{l}- \\
3 \\
- \\
3\end{array}$ & $\begin{array}{c}- \\
100 \\
- \\
100\end{array}$ & $\begin{array}{l}- \\
2 \\
- \\
2\end{array}$ & $\begin{array}{c}- \\
100 \\
- \\
100\end{array}$ & $\begin{array}{c}- \\
24 \\
- \\
24\end{array}$ & $\begin{array}{c}- \\
100 \\
- \\
100\end{array}$ \\
\hline TDS (mg/l) & $500-1000$ & $\begin{array}{c}<500 \\
500-1000 \\
>1000 \\
\text { T0tal }\end{array}$ & $\begin{array}{c}27 \\
- \\
- \\
27 \\
\end{array}$ & $\begin{array}{c}100 \\
- \\
- \\
100 \\
\end{array}$ & $\begin{array}{l}6 \\
- \\
- \\
6 \\
\end{array}$ & $\begin{array}{c}100 \\
- \\
- \\
100\end{array}$ & $\begin{array}{l}3 \\
- \\
- \\
3\end{array}$ & $\begin{array}{c}100 \\
- \\
- \\
100\end{array}$ & $\begin{array}{l}1 \\
1 \\
- \\
2\end{array}$ & $\begin{array}{c}50 \\
50 \\
- \\
100 \\
\end{array}$ & $\begin{array}{c}24 \\
- \\
- \\
24 \\
\end{array}$ & $\begin{array}{c}100 \\
- \\
- \\
100 \\
\end{array}$ \\
\hline $\mathrm{Cl}^{-}(\mathrm{mg} / \mathrm{l})$ & 250 & $\begin{array}{l}<250 \\
>250 \\
\text { Total }\end{array}$ & $\begin{array}{c}7 \\
- \\
27\end{array}$ & $\begin{array}{c}100 \\
- \\
100\end{array}$ & $\begin{array}{l}6 \\
- \\
6\end{array}$ & $\begin{array}{c}100 \\
- \\
100\end{array}$ & $\begin{array}{l}3 \\
- \\
3\end{array}$ & $\begin{array}{c}100 \\
- \\
100\end{array}$ & $\begin{array}{l}2 \\
- \\
2\end{array}$ & $\begin{array}{c}100 \\
- \\
100\end{array}$ & $\begin{array}{c}24 \\
- \\
24\end{array}$ & $\begin{array}{c}100 \\
- \\
100\end{array}$ \\
\hline $\mathrm{NO}_{3}{ }^{-}(\mathrm{mg} / \mathrm{l})$ & 50 & $\begin{array}{c}<50 \\
>50 \\
\text { Total }\end{array}$ & $\begin{array}{c}27 \\
- \\
27 \\
\end{array}$ & $\begin{array}{c}100 \\
- \\
100 \\
\end{array}$ & $\begin{array}{l}6 \\
- \\
6 \\
\end{array}$ & $\begin{array}{c}100 \\
- \\
100 \\
\end{array}$ & $\begin{array}{l}3 \\
- \\
3 \\
\end{array}$ & $\begin{array}{c}100 \\
- \\
100\end{array}$ & $\begin{array}{l}2 \\
- \\
2\end{array}$ & $\begin{array}{c}100 \\
- \\
100 \\
\end{array}$ & $\begin{array}{c}24 \\
- \\
24 \\
\end{array}$ & $\begin{array}{c}100 \\
- \\
100 \\
\end{array}$ \\
\hline
\end{tabular}

Key: DO-dissolved Oxygen, EC-electrical Conductivity, TDS-total dissolved Solids, $\mathrm{Cl}^{-}$-chloride ion, $\mathrm{NO}_{3}^{-}-$ nitrate ion.

\subsection{Bacteriological Parameters}

\subsubsection{Total Coliform (TC)}

The mean TC value recordedinUnprotected Spring on spot, protected spring with distribution system, unprotected Hand dug well, Unprotected River and Tap water were 15.41 $\pm 1.96,29.33 \pm 1.64,84.66 \pm 11.55$, $342.5 \pm 255.5$ and $12.00 \pm 1.25 \mathrm{in} \mathrm{cfu} / 100 \mathrm{ml}$ respectively (Table 5). The maximum mean value was observed in Unprotected River $(342.5 \pm 255.5 \mathrm{cfu} / 100 \mathrm{ml})$ and the minimum mean value was recorded in Tap water $(12.00 \pm 1.25 \mathrm{cfu} / 100 \mathrm{ml})$.

Analysis of the current62 water samples demonstrated that $100 \%$ of the samples had TC as indicator bacteria which is similar to the research conducted in Yubdo-Legebatu by Birhanu(2008) indicated that all the water samples were contaminated by the total coliform in which the highest total coliform was 1447.47 $\mathrm{cfu} / 100 \mathrm{ml}$ and the lowest coliform was $193.8 \mathrm{cfu} / 100 \mathrm{ml}$ that was much higher than the present study which did not meet WHO and ESDWQ guideline that is 0cfu/100ml (WHO, 2003; ESDWQ,2002) (Table 5 and 6).

Additionally, the maximum concentration of TCwas observed in unprotectedriver $(342.5 \mathrm{cfu} / \mathrm{ml})$ (Table 5) particularlyUR1 $(598 \mathrm{cfu} / 100 \mathrm{ml})$ (Table 6) which is supported by the research conductedat Gondar town showed that the average concentrations of total coliform of Shinta river was $143 \mathrm{cfu} / 100 \mathrm{mlbutlower}$ than the present study (Birtukan et al., 2014). The second highest concentration of TC was recorded in UHDW (84.66cfu) which had higher range of total coliform thana study conducted on rural hand-dug well of South Wello by Atnafu (2006) that contain $3.3 \mathrm{CFU} / 100 \mathrm{ml}$ and the possible reasons for these variation might be differences in the time of the research conducted (seasonal influence for example rainfall) and some environmental condition like temperature, amount of dissolved oxygen and sources of contaminants. 


\subsubsection{Faecal coliform (FC)}

The highest mean FC concentration recorded from the samples was $82.5 \pm 23.5 \mathrm{cfu} / 100 \mathrm{ml}$ from Unprotected river mainly UR1followed by $31.66 \pm 6.98 \mathrm{cfu} / 100 \mathrm{ml}$ from Unprotected Hand dug well Table 5. The lowest mean FC concentration recorded was $12.59 \pm 1.20,10.33 \pm 1.85$, and $5.25 \pm 0.78 \mathrm{in} \mathrm{cfu} / 100 \mathrm{ml}$ from Unprotected Spring on spot, protected spring with distribution system and Tap water respectively (Table5). Therefore, the values were greater than WHO and ESDWQacceptable limit which is nil for both TC and FC cfu/100ml (Table 6). Research conducted in North Gonder by Mengesha(2004), demonstrated that 50\% of the samples had more than 180 coliform count per $100 \mathrm{ml}$ and the lowest coliform count was $13 \mathrm{cfu} / 100 \mathrm{ml}$ which is higher than the samples conducted under this study that had no more than $106 \mathrm{cfu} / 100 \mathrm{ml}$ with the highest and $0 \mathrm{cfu} / 100 \mathrm{ml}(6.45 \%)$ with the lowest (Table 6)

\subsection{Sanitary Survey}

According to sanitary survey inspection on the study area(data not shown), $71 \%$ of the rural residents were lived together with livestock and farming animals in one way or another, $33 \%$ of the rural residents stored water in open jugs that may facilitate the contamination of containers with microorganisms. Furthermore, $63 \%$ of rural residents were defecated their wastes in open field but only $37 \%$ used their own toilet which is pit latrine, $75.0 \%$ urban and $100 \%$ rural residents did not have habit to wash their hands after defecation and dispose refuse in the open fields, which is consistent with the study made in south Ethiopia by Teferi (2007) where only 3.6\%of water samples taken from storage containers were in compliance with WHO guidelines $(0 \mathrm{cfu} / 100 \mathrm{ml})$ and $33.7 \%$ of the residents used open field defecation.

Therefore, for bacterial concentration(FC) observed through laboratory analysis, the rural residents that lived together with livestock and farming animals in one way or another, storageof water in open jugs, disposal of their wastes and refuse in the open fields, inadequate sanitation facilities and lack of good hygiene obtained throughsanitary inspection might be the main factors for the faecal contamination of all water sources particularly unprotected River and Hand dug wellsthat have a great potential to introduce a variety of intestinal pathogens (Mengesha et al., 2004) sinceit is impossible to isolate the sanitation and hygiene practices from the water quality perspective (water aid, 2009).

The greatest microbiological risks associated with water contamination are human or animal faeces, pathogenic bacteria, viruses and parasites (protozoa and helminthes or worms) which are the main causes for the outbreak of infectious diseases (WHO, 2004, 2006). In regularly checked water sources the E.colicount should have been zero per $100 \mathrm{ml}$ (WHO, 2004). This fact is only observed in 4(6.45\%) from 62 analyzed samples of the protected water sources that is Tap water (Table 6).

From this point of view, study conducted in Digalu-Tijo woreda showed that total sanitary risk score had a significant relationship with level of contamination (data not shown). Table 5below demonstrated thatunprotected River was highly contaminated with TC and FC followed by unprotected Hand dug well. However, tap water was relatively better in bacteriological contamination as compared to other water sources.

Table 5. Mean \pm SEM Statistical analysis of Bacteriological parameters of Drinking water samples from different sources.

\begin{tabular}{lccc}
\hline \multicolumn{1}{c}{ Water sources } & $\mathrm{n}$ & Total coliform $(\mathrm{cfu} / 100 \mathrm{ml})$ & Faecal coliform $(\mathrm{cfu} / 100 \mathrm{ml})$ \\
\hline USOS & 27 & $15.41 \pm 1.96$ & $12.59 \pm 1.20$ \\
PSWDS & 6 & $29.16 \pm 1.64$ & $10.33 \pm 1.85$ \\
UHDW & 3 & $84.66 \pm 11.55$ & $31.66 \pm 6.98$ \\
UR & 2 & $342.5 \pm 255.5$ & $82.5 \pm 23.5$ \\
TW & 24 & $12.00 \pm 1.25$ & $5.25 \pm 0.78$ \\
\hline
\end{tabular}

Key: USOS-unprotected spring on spot, PSWDS-protected spring with distribution system, UHDW-unprotected hand dug well, UR-unprotected River, TW-tap waters-standard deviation, SE-standard error.

Table 6 below showed that $100 \%$ of the 62 water samples have TC with the highest concentration in UR1 $(598 \mathrm{cfu} / 100 \mathrm{ml})$ followed by UHDW1 $(94.5 \mathrm{cfu} / 100 \mathrm{ml})$ and $93.55 \%$ of the present water samples had FCwith the highest concentration in UR1 $(106 \mathrm{cfu} / 100 \mathrm{ml})$ followed by UR2 $(59 \mathrm{cfu} / 100 \mathrm{ml})$.From these only $6.45 \%$ of the present water sample agreed with WHO and ESDWQ and TW was relatively more suitable than others particularly TW3. 
Table 6. Mean concentration of Bacteriological analysis of Drinking water sample from different sources

\begin{tabular}{|c|c|c|c|c|c|c|c|c|}
\hline \multirow[b]{2}{*}{ Sites } & \multirow[b]{2}{*}{$\begin{array}{l}\text { Water } \\
\text { points }\end{array}$} & \multirow[b]{2}{*}{$\mathrm{N}$} & \multicolumn{3}{|c|}{ Total coliform } & \multicolumn{3}{|c|}{ Faecal coliform } \\
\hline & & & $\begin{array}{c}\text { In } \mathrm{Cfu} / 100 \mathrm{ml} \\
\text { Of each water } \\
\text { point }\end{array}$ & $\begin{array}{c}\text { №of } \\
\text { sample } \\
\text { having TC }\end{array}$ & $\%$ & $\begin{array}{c}\text { In } \mathrm{Cfu} / 100 \mathrm{ml} \\
\text { Of each water } \\
\text { point }\end{array}$ & $\begin{array}{c}\text { №of sample } \\
\text { havingFC }\end{array}$ & $\%$ \\
\hline \multirow{3}{*}{1} & USOS1 & 9 & 17.33 & 9 & 100 & 12.66 & 9 & 100 \\
\hline & PSWDS & 3 & 29.00 & 3 & 100 & 11.33 & 3 & 100 \\
\hline & TW1 & 8 & 11.37 & 8 & 100 & 5.37 & 7 & 87.5 \\
\hline \multirow{3}{*}{2} & USOS2 & 9 & 15.11 & 9 & 100 & 12.44 & 9 & 100 \\
\hline & HDW1 & 2 & 94.5 & 2 & 100 & 38.50 & 2 & 100 \\
\hline & TW2 & 8 & 13.62 & 8 & 100 & 5.87 & 7 & 87.5 \\
\hline & UHDW2 & 1 & 65.00 & 1 & 100 & 18.0 & 1 & 100 \\
\hline 3 & UR1 & 1 & 598.00 & 1 & 100 & 106.0 & 1 & 100 \\
\hline \multirow[t]{2}{*}{4} & USOS3 & 9 & 13.77 & 9 & 100 & 12.66 & 9 & 100 \\
\hline & UR2 & 1 & 87.0 & 1 & 100 & 59.0 & 1 & 100 \\
\hline \multirow[t]{2}{*}{5} & PSWDS2 & 3 & 29.33 & 3 & 100 & 9.33 & 3 & 100 \\
\hline & TW3 & 8 & 11.00 & 8 & 100 & 4.50 & 6 & 75 \\
\hline \multirow{3}{*}{\multicolumn{2}{|c|}{$\begin{array}{l}\text { Samples equal to } \\
\quad \text { WHO value } \\
\text { Samples more than } \\
\text { WHO value }\end{array}$}} & - & - & - & - & - & 4 & 6.45 \\
\hline & & & & & & & & \\
\hline & & 62 & & 62 & 100 & & 58 & 93.55 \\
\hline
\end{tabular}

Key: TC-total coliform, FC-faecal coliform, cfu-coliform unit

\section{Conclusion and Recommendation}

The main objective of this Research work was to assess the status of drinking water quality in DigaluTijoworeda. Based on the physico-chemical and Bacteriological analysis and sanitary survey inspection of the present research findings; the following conclusions have been drawn: All the physico-chemical parameters of all water sources in Digalu-Tijo woreda were found within and below the range of National and International standards except Turbidity, $11.1 \%$ of Unprotected spring on spot, $100 \%$ of Unprotected Hand dug wells and unprotected Rivers, Temperature (100\% of protected spring with distribution system,Unprotected Hand dug well, Unprotected River andTap water)and $\mathrm{pH}(7.4 \%$ of Unprotected spring on spot) which hadabove National and International permissible standards that mayresult to a cause of serious public health problem over long time exposure.

The overall bacterial count and sanitary risk factor assessment indicated that the majority of water sourcescould be classified as intermediate range. However, the bacteriological counts in Unprotected Hand dug wells and unprotected Rivers were in the dangerous range of pollution. The bacteriological counts of indicator organisms in all sampled water sources of the study area suggested that there are thepresences of pathogenic organisms that constitute a threat to anyone consuming those water sourcesand therefore, majority of water sources ( $93.55 \%$ of water samples) did not meet national and international guidelines (unacceptable) for drinking.

The contamination of all water sources $(96 \%$ were unprotected) with enteric organisms can be explained in part by absence of fencing that prevent the entrance of animals; livestock grazing nearby water sources, people's open area defecation, and agricultural activities nearby water sources. Moreover, poor sanitation, low level of hygiene education, poor irregular disinfection, and uncontrolled of related parameters to efficient disinfection processes can also be cause for water sources contamination.

So, majority of water sources, particularly unprotected Rivers and Hand dug wells were not suitable for drinking because Unprotected River2 (Gusha river) was the highest in the concentration of Turbidity, EC, TDS, $\mathrm{Cl}^{-}$and $\mathrm{NO}_{3}^{-}$followed by Unprotected River1 (Kater river) which was higher in Temperature, TC and FC. Moreover, Unprotected Hand dug wells1was the highest with TC. However, Tap water 3 was relatively suitable source of water than others followed by Tap water 1 and Tap water 2 .

On the basis of these findings, to ensure compliance to clean and quality water, minimizing fecal contamination of water with livestock and human wastes will have a dramatic impact on reducing water sources pollution in the study area. Besides, it calls for appropriate intervention, including awareness development work, strengthening local water quality monitoring and control system as well as risk assessmentand management mechanismsby local authorityand improving the existing infrastructure in order to minimize the potential health problems of those communities currently realizing of the available water sources.

\section{REFERENCE}

AberaKuime and Mohamed Ali (2005): An over view of environmental health statusin Ethiopia with particular emphasis to its organization, drinking water and sanitation: A literature survey. Ethiopia. 
J .health Dev. 19, (2):83-103.

APHA (1992): Standard Methods for Examination of Water and Waste Water.America Public Health Association, 17th edition.Pp. 1268-70.

American Public Health Associations (APHA) (1998): Standard Methods for the Examination of Water and Waste Water. American People Health Association, $20^{\text {th }}$ ed, Washington DC.

Andrea,V., Parpinello G.P. and Galassi, S (2002): Journal of food composition and analysis. 15: 251.

Akoto, O and Adiyiah, J (2007): Chemical analysis of drinking water from some communities in the brongahaforegion. International Journal of Environmental Science and Technology, 4(2):211-214.

Atnafu Melese (2006): Assessment of Bacteriological Quality of Drinking Water Supply at the sources and Point of Use at Home in Worebabu District, South Wollo. M.Sc. Thesis. Addis Ababa University, Addis Ababa.34-57.

American Water Works Association (AWWA) (2000): Introduction to Water Quality Analysis, v.4, Colorado, USA. pp. 23-39, 81-104.

Barrell, R., Hunter, P.R. and Nichols, G. (2002): Microbiological standards for water and their relationship to health risk. Commun. Dis. Public Health, 3: 8-13.

Bartram, J., Lewis, K., Linton, R. and Wright, A (2005): Focusing on improved water and sanitation for health.Lancet [Lancet], 365(9461): 810-812.

Birhanu Million (2008): Assessment of the contamination level of water and determines the major sources of contamination at water collection point in Yubdo-Legebatu River, M.SC. Thesis.Addis Ababa University Ethiopia. P. 34- 65.

Birtukan Getahun, Feleke Moges and Berhanu Andualem (2014): Physico-Chemical and Bacteriological Quality of Water from Different Sources in Gondar Town. World Applied Sciences Journal 32 (9): 1800-1807

Bhatt, L.R., Lacoul, P., Lekhak, H.D., Jha,P.K. and Lance,V.A (2000): Assessment of water pollution 1999.Physicochemical characteristics in the Narayani river, Nepal. Intern. J. Ecol. Environ. Phytoplankton of Taudaha Lake, Kathmandu. Poll. Sci., 26: 235-252. Res.,18(14): 353-358

Burgess, J.E. and Pletschke,B.I. 2008.Microbiological water quality assessment (Catchment to tap).Journal of Water and Health Science 58: 1467-1473.

Byamukama, F.Kansime, D., Mach, L. and Farnleitner. A (1999): Determination of Escherichia coli contamination with chromo cult coliform agar for differing pollution levels in tropical waters showed a high level of discrimination efficiency for differing Pollution levels in tropical waters of Kampala, Uganda. Appl Environ Microbial. 66: 864-868

Chan, C.L., Zalifah, M.K. and Norrakiah, A.S (2007): Microbiological and physicochemical quality of drinking water. Malaysian Journal of Analytical Sciences, 11(2): 414-420

Chapman, D (1996) Water Quality Assessment: A Guide to the use of Biotic, Sediments and Water in Environmental Monitoring 2nd edition. Chapman and Hall, Landonpp, 1-15

Cochran, W.G. (1963): SamplingTechniques. $2^{\text {nd }}$ ed.John Wiley and sons, Inc. New York.

Clesceri, L., Greenberg A.E. and Eaton.A.D. 1998. Standard methods. $20^{\text {th }}$ editions. American Health Association, Baltimore (USA).pp. 1-3

Dada, A. and Ntukekpo, D.S (1997): Pure water; How safe? Ultimate water technology and EnvironmentDigaluTijoWoreda Health office.2015.Annual Report. Sagure.

Digalu-Tijo woreda Atlas (2015).

Ethiopian Standard (ES 261:2001) (2001): Ethiopian standard of drinking water-specifications. Secondedition.Quality and Standards Authority of Ethiopia ES 261:2001.pp1-7. www.qsae.org

Ethiopian Standard for Drinking Water Quality (ESDWQ) (2002): Ethiopian Standard for Drinking Water Quality Guidelines, Ministry of Water Resources, Addis Ababa, Ethiopia

EshetuKebede.2016.Assessment on the physicochemical properties of drinking water in

Faris, K. and Kaba, M (1999): Hygienic Behavior and Environmental condition in Jimma town. Ethiopian Journal of Health Development 13(2):77-86.

FAO (2002): Prevention of Water Pollution by Agriculture. Santiago, ChileJ.A.pp.295-302.

FDRE, Ministry of Water Resources (2002): Water sector development program 2002- 2016.Main report document, Addis Ababa, Ethiopia.

FDRE, Ministry of Water Resources (2004): Water supply safety measures extension package. Federal Democratic Republic of Ethiopia, Ministry of Water Resources, Addis Ababa, Ethiopia.

Gebrekidan Mebrahtu and Samuel Zerabruk (2011): Concentration of Heavy Metals in Drinking Water from Urban Areas of the Tigray Region, Mekelle University.

HACH (2010): DR/2010 spectrophotometer instrument manual. HACH Company, Colorado, USA.

Hem, J (1985): Study and interpretation of the chemical characteristics of natural water. Denmark

Howard, G., InceM. and Smith, M (2003): Rapid Assessment of Drinking Water Quality: Handbook for Implementation-Joint Monitoring for Water Supply and Sanitation. WEDC, Loughborough 
University.ISBN 184380 042. PP: 1-87.

Hutton (1996): Field water sampling techniques for developing countries.

Kar, D., Sur, D.P., K. Mandal, S., Saha, T. and Kole, R.k (2008): Physco-chemical Analysis of Drinking Water Source. International Journal of Environmental Science and Technology.5: 11.

Kent, J.P., Greenspan J.R. and Herndon, J.L (1988): Epidemic Giardiasis caused by contaminated public water supply. Am. J Public Health.78:139-43

Kothari, C.R (1990): Research Methodology, Method and Techniques, $2^{\text {nd }}$ Revised ed. College of Commerce, University of Rajasthan, India

Kumar, P.B., Dushenkov, V., Motto, H. and Raskin, I (1996): Phytoextraction: The use of plants to remove heavy metals from soils. Environ. Sci. Technol. 29(5):1232-1238

London, L., Dalvie, M.A., Nowickiand, A. and Cairncross, E (2005): Approaches for regulating water in South Africa for the presence of pesticides. Water SA 31(1):53-60

Melaku, S., Wondimu, T., Dams, R. and Moens, L (2007): Pollution Status of Tinishu Akaki River and Its Tributaries (Ethiopia) Evaluated Using Physic-Chemical Parameters, Major Ions and Nutrients. Bull. Chem. Soc. Ethiop., 21(1):13-22.

Mengesha Admassu, Mamo Wubshet and Baye Gelaw (2004): A survey of bacteriological quality of drinking water in North Gondar. Ethiopian Journal of Health Development 18(2):113-135.

Muyima, N. and Ngcakani, F (1998): Indicator bacteria and re-growth potential of the drinking water in Alice, Eastern Cape.Dep. J. of Biochem. And Microbial. 24(1) pp.: 29-34 ISSN 0378- 4738 University of Fort Hare, South Africa.

Onuh, J. O. and Isaac V.U (2009): Physico-Chemical and Microbiological Quality of water sources from some major towns in Igala land. Nigeria food Journal 27(2):66-72.

Qadeer, R (2005): Analysis of physico-chemical properties and heavy metals in drinking water. Journal of the Chemical Society of Pakistan 26: 293.

Rodier, J. 2009.The water analysis, 9th edn, Paris.

Sisti, M., Albaino,A. and Brandi, G. 1998.Bacteriological effect of chlorine on motile Aeromones spp, in drinking water supplies and influence of temperature on disinfection efficiency. Appl.Micro.26:347-351, Institute of Toxicological, Hygienic and Environmental Science, University of Urbino, Italy.

Staci, N (2005): William's Basic Nutrition and Diet Therapy.ELSEVIER MOSBY.1:156165.

TamiruAlemayehu. 2005. The Impact of Uncontrolled Waste disposal on Surface Water Quality in Addis Ababa, Ethiopia. SINET: Ethiop. J. Sci., 24(1):93-104.

Teferi Abagaz (2007): Assessment of knowledge and hygienic practices towards bacteriological quality of drinking water at Dobo Togo kebeles shebedino woreda. M.SC. Thesis. Hawassa university, Hawassa, Ethiopia.p36.

Tihansky, D.P (1974): Economic damage from residential use of mineralized water supply. Water Resources Research. 10(2): 145-154

Trivedi, P., Bajpai, A. and Thareja, S (2010): Comparative Study of Seasonal Variation in Physico-Chemical Characteristics in Drinking Water Quality of Kanpur, India With Reference To 200 MLD Filtration Plant and Ground Water.Nature and Science. 8(4): 1117

United States Environment protection agency (USEPA) (1997): Water pollution prevention and conservation pollution.

United States Environment protection agency (USEPA) (2001): Parameter of Water Quality interpretation and standards. Published by the Environmental Protection Agency, Ireland

UN-WATER/WWAP/ (2004) United Nations Educational, Scientific, and Cultural Organization World Water Assessment Program .National Water Development Report for Ethiopia. Addis Ababa. December 2004.

Water Aid (2009): Water, sanitation and hygiene for development.Advocacy for Change.

World Health Organization (WHO).1983.Integrated Vector Control. Seventh report of the WHO Expert Committee on Vector Biologyand Control, Technical Report Series No. 688, World Health Organization, Geneva, p.72.

World Health Organization (WHO) (1993): Guidelines for Drinking-Water Quality.Vol.12 ${ }^{\text {nd }}$ ed. Recommendations Geneva, Switzerland.

World Health Organization (WHO) (1996): Guidelines for Drinking-Water Quality - Second Edition - Volume 2 Health Criteria and Other Supporting Information. International Programme on Chemical safety. World Health Organization. ISBN 9241544805 Geneva. PP: 1-94

World Health Organization (WHO) (2003): Technical Support Document for Ontario Drinking-water Quality Standards, Objectives and Guidelines. Ministry of the Environment

World Health Organization (WHO) (2003: Chloride in drinking-water: Background document for preparation of WHO Guidelines for drinking-water quality. Geneva, World Health Organization (WHO/SDE/WSH/03.04/3). 
World Health Organization (WHO) (2003a): Water, sanitation and health. Geneva, World Health Organization.

World Health Organization (WHO): 2004. Guideline for drinking water quality, supporting Documentation to the Guidelines 3rd Edition. Geneva, Switzerland.

World Health Organization (WHO) (2004a): Guidelines for Drinking Water Quality, 3rd Edition. World Health Organization Geneva: 143.

World Health Organization (WHO). 2004a. Water Treatment and Pathogen Control: Process Efficiency in Achieving Safe Drinking Water. Edited by Mark W LeChevallier and Kwok-Keung Au. ISBN:1 84339 06988. IWA, London, UK. World Health Organization. PP: 1-12.

World Health Organization (WHO) (2004b): Guidelines for drinking -Water Quality. Third Edition, Vol.1: Recommendation. World Health Organization, Geneva

World Health Organization (WHO) (2006): In Water, Sanitation and Health World Health Organization-Water Quality. Third Edition, Vol.1: Recommendation.

World Health Organization (WHO) (2010): Water for health: WHO Guidelines for Drinking-water Quality, WHO Geneva, Switzerland.

World Health Organization (WHO) (2011): Guidelines for drinking water quality. Recommendations $4^{\text {th }}$ ed. 564p. www.who.int/.../en/

Zewdie Abate (1994) Water Resources Development in Ethiopia: An Evaluation of Present and future planning concepts. Ithaca Press Reading. UK.

Zinabu Assefa, Kirubel Tesfaye, Tsigereda Assefa and Sisay Derso (2015): Physicochemical quality of drinking water sources in Ethiopia and its health impact: a retrospective study Researchers at Ethiopian Public Health Institute, Environmental Health Research team. 